\title{
Interpreting meaning in police interviews: Applied Language Typology in a Forensic Linguistics context
}

\author{
Luna Filipović \\ University of East Anglia Norwich, UK \\ l.filipovic@uea.ac.uk \\ Alberto Hijazo-Gascón \\ University of East Anglia Norwich, UK \\ a.hijazo-gascon@uea.ac.uk
}

\begin{abstract}
The main aim of this paper is to raise awareness about the importance of language contrasts in legal interpreting contexts. The semantic typology of motion events put forward by Talmy $(1991,2000)$ and its implications for discourse and narrative (Slobin 1991, 1996, 2004, 2005) are used as an example of how an applied typology approach can be useful for the analysis of language contrasts in a forensic linguistics context. Applied Language Typology (Filipović 2008, 2017a, b) is used here to analyse transcriptions of police interviews that were mediated by an English-Spanish interpreter in California (USA) and an English-Portuguese interpreter in Norfolk (UK). The results of this analysis demonstrate that certain differences in semantic components of motion such as Manner, Cause and Deixis can lead interpreters to add, omit or modify the content of a message in the process of translation. This leads us to conclude that professional practices such as the production of bilingual transcripts and use of control interpreters, together with the inclusion of Applied Language Typology in interpreting training, would improve the quality of interpreting practices in legal contexts.
\end{abstract}

Keywords: Forensic Linguistics, Applied Language Typology, Motion Events, Translation and Interpreting, Cognitive Linguistics

\section{Resumen}

El principal objetivo de este artículo es el de llamar la atención sobre la importancia de los contrastes lingüísticos en contextos de interpretación legal. La tipología semántica de los eventos de movimiento propuesta por Talmy $(1991,2000)$ y sus implicaciones para el discurso y el estilo retórico (Slobin 1991, 1996, 2004, 2005) 
se utilizan para ejemplificar cómo un enfoque de tipología aplicada puede ser de utilidad para el análisis de estos contrastes lingüísticos en contextos de lingüística forense. En este artículo se utiliza la Tipología Lingüística Aplicada (Applied Language Typology en inglés, Filipović 2008, 2017a,b) para analizar transcripciones de interrogatorios policiales en las que participaron intérpretes ingles-español en California (EE.UU.) e ingles-portugués en Norfolk (Reino Unido). Los resultados de este análisis demuestran que las diferencias en la expresión de ciertos componentes semánticos del movimiento como la Manera, la Causa y la Deixis pueden provocar que los intérpretes añadan, omitan o modifiquen el contenido semántico del mensaje durante el proceso de traducción. Concluimos señalando los beneficios de distintas prácticas como la producción de transcripciones bilingües de los interrogatorios, la inclusión de intérpretes de control y la enseñanza de Tipología Lingüística Aplicada en la formación de intérpretes. Estas medidas profesionales mejorarían la calidad de la interpretación en contextos legales.

Palabras clave: Lingüística forense, tipología del lenguaje aplicada, eventos de movimiento, traducción e interpretación, lingüistica cognitiva

\section{Introduction}

In this paper we illustrate the ways in which forensic linguistic research, driven by insights from a language typology, can help us understand and resolve certain issues that arise in a specific professional context, i.e. interpreter-mediated police interviews. The reason for focusing on this specific context is motivated by its social importance. The consequences of linguistic difficulties on this occasion can go beyond the communicative situation and have an impact on real-life outcomes, such as whether a person is found innocent or guilty, or understood to be telling the truth or lying. In our study we go beyond the mere detection of the key language contrasts that may cause problems in translation in order to outline their actual and potential real-life consequences. Applying language typology to data analysis in this specific context enables us to account for and predict communicative (and potential material) outcomes and to indicate a wider scope of applications for this kind of research as well as a wider range of professional contexts for which this research can provide valuable and practically useful insights.

We start by presenting a cursory glimpse at the field of forensic linguistics and we discuss some previous studies that shared some of the concerns addressed in our paper. This necessarily selective review of literature refers to research with cross-linguistic contrastive approach in forensic linguistic contexts even though the research presented may not have been framed in typological terms or may belong to the broader area of 
language and the law studies rather than forensic linguistics per se (section 2). The aim of the literature discussion is therefore to illustrate the kind of problems researchers and practitioners face in the context of police and other legal interviews rather than offer a critical account of different approaches, methodologies and findings or compare these to ours. This is because our approach is very novel and hardly any other studies have attempted this kind of finely grained interdisciplinary analysis, carried out on a large database of bilingual police interviews. Our previous and current work is therefore paving a new way for a number of related research areas, namely forensic linguistics, applied language typology studies, psycholinguistics, criminology and translation and interpreting studies.

We begin by situating our work within the field of forensic linguistics, and then focus on the specific topic of this paper within that field, namely interpreter-assisted communication in police interviews. We introduce the main tenets of Applied Language Typology as the framework for our research (Filipović 2008, 2017a, b), and illustrate how it informs our analysis of the interview data (section 3). We focus on the cognitive domain of motion events and the components of Manner, Cause and Deixis. This decision is a principled one because these components are crucial for our understanding of what happened, how, why and when events are described and translated. For instance, based on information about how somebody moved (e.g. running vs. limping), police officers can draw inferences about whether the person they are looking for is near or far from the crime scene or whether the person is hurt and moving with difficulty or not. Speakers of typologically different languages differ with regard to how much and how often they talk about manner of motion due to the typologically different means their languages provide them with (Slobin 1996b, 2003, 2006). Similarly, in relation to caused motion, some languages have distinct constructions for distinguishing between intentional and non-intentional events and they habitually use them. Others have one and the same construction for both event types. This results in consistent distinctions being drawn in one language (or language type) while another language (or language type) provides event descriptions that are ambiguous with respect to intentionality (Filipović 2013a, 2013b, 2016). The role of deixis cannot be underestimated, since it can be of key importance to specify where the speaker (e.g. a witness) was positioned with respect to the event described (e.g. whether a suspect or a victim was moving towards or away from the speaker and thus we can infer the perspective or angle that the event was witnessed from; Filipović 2007a, Hijazo-Gascón 2017).

In section 4 we offer insights into what we can discover when we use an applied typology approach for the puropse of a forensic linguistic analysis of police interviews. We highlight the practical consequences (real, such as misunderstanding 
or misinterpretation and potential, such as miscarriage of justice and unequality in access to justice) of unresolved (or wrongly resolved) issues in interpreter-mediated communication that involves police officers, interpreters and suspects. We conclude with a summary of our findings and suggestions for further research (section 5).

\section{Forensic Linguistics and Interpreting}

\subsection{Forensic linguistic approaches to the analysis of police interviews}

It is impossible to give justice to forensic linguistics, a rapidly developing specialised branch of applied linguistics, in the restricted space we have on this occasion. There are fortunately a few good introductory publications (e.g. Coulthard and Johnson 2007, Olsson 2008) as well as comprehensive compilations of numerous research themes and strands already being pursued in the field (e.g. The Routledge Handbook of Forensic Linguistics edited by Coulthard and Johnson 2010 and The Oxford Handbook of Language and the Law edited by Solan and Tiersma 2012). Our goal here, however, is not to provide an overview of this discipline but rather to situate our work within it. We therefore give a very brief and necessarily selective account that tackles some key research themes, with a focus on studies that share concerns related to ours.

The start of forensic linguistics is often said to be marked by a paper entitled The Evans statements: A case for forensic linguistics by Jan Svartvik (1968). Since then, the discipline has been growing exponentially to include a variety of overlapping points of interest in the areas of language and the law. This is why the discipline is in fact truly and inherently interdisciplinary, since linguists, lawyers, psychologists, police officers and language professionals have been providing immensely valuable insights from different perspectives, thus throwing an eclectic light on complex issues that are hard to deal with by a single discipline or with the use of a single approach.

When it comes to data for analysis, forensic linguistics studies any forensically relevant linguistic communication, spoken or written. A communication is relevant if it has a role in a criminal investigation or a legal process, e.g. a contract, a personal letter or a recorded conversation. Police interview recordings and interview transcripts are one example of forensically relevant communication. Previous research has demonstrated the immense value that this kind of study affords. For instance, it was precisely the analysis of statements given in a police interview that contributed to the exoneration of wrongly accused people in the Birmingham Six case. Namely, forensic linguistic analysis of alleged verbatim statements by the suspects were shown not to be verbatim but rather elaborations by police officers. This was detected using discourse 
analysis, which showed numerous traits of specific police discourse style such as specialised vocabulary, repetitive use of certain specific phrases and cohesion devices and other policespeak formulations that ordinary speakers are extremely unlikely to use (see Coulthard and Johnson 2007 for details).

Research on police interviews can be considered one of the central areas of interest for forensic linguistic analysis since police interviews are types of communicative situations that are central to criminal investigation and can be used as evidence in criminal proceedings in court. Previous research on language in police interviews (monolingual or bilingual) has provided a few important insights from a variety of angles. In most cases, researchers have approached the research questions from a sociolinguistic or discourse analysis perspective and discussed aspects of interaction such as turn taking or power relations between the interlocutors (interviewer ws. interviewee; see e.g. Heydon (2005) for an overview and detailed exemplification). It is also worth pointing out that most of the research in the past has been done on English or in monolingual contexts. In more recent years due to an increased mulilingualism in societies, and consequently legal contexts as well, there is an increase in valuable cross-linguistic and psycholinguistic research. For instance, Kredens (2016) discusses various situational contexts in which officers and interpreters can interact successfully by sharing common interest in effective communication. A recent brief yet very informative publication focuses specifically on police investigative interviewing and interpreting and exemplifies the numerous challenges and complexities that both police offcers and interpreters have to navigate in the context of police investigative interviewing (Mulayim, Lai and Norma 2015). The increased focus on interpreting and translation in police contexts has revealed that there is a need for more joint research and joint training of law enforcement, legal professionals and police interpreters, which is precisely the aim of our research project presented in this paper (see section 4).

We have to emphasise here that because our focus is on communication conflicts due to language contrasts, we do discuss the often mentioned overall interpreting challenges and interpreter conduct issues, but we acknowledge here that numerous factors, in addition to language contrasts, do play a signficant role in the outcomes of police communication involving interpreters. The cognitive effort required for performing interpreting tasks cannot be underestimated (see discussion in de Groot 1997; Gile 1997; MacWhinney 1997). Neither can we disregard the difficulty of negotiating the unenviable position of the interpreter in this context, whose multifunctional role is defined in numerous ways in different contexts (e.g. as cultural mediators or facilitators; see Tipton 2010), which some may still expect them to be, although in the legal setting it is inappropriate to be anything but a "mouthpiece" or 
a "conduit", as Mulayim, Lai and Norma (2015:16) point out, since the exchanges are entered into evidence as being made by the interviewer and the interviewee, not by the interpreter. We now turn to a more detailed discussion of those studies that analysed multilingual legal communication in more depth and that delved into the details of language contrasts and intepreting difficulties that stem from those contrasts.

\subsection{Interpreter-mediated police communication: A closer look}

The bilingual, or rather mutilingual, trend in forensic linguistics is gaining pace but there is still much work to be done, especially when it comes to the detailed study of typological language contrasts and their effects in legal contexts. The research discussed here could be seen as paving a new way towards a future development of the discipline. This new way should, in our opinion, include typological insights that systematically highlight similiarities and differences between languages or language types and focus on the effects of these similarities and differences in multilingual exchanges. We need more studies in this vein, which will include detailed, finely grained analyses and documentation of precise points of conflict that are due to typologically different syntactic, lexical and pragmatic features.

It is of relevance to point out that work in the legal communication context of police interpreting has a number of practical obstacles. Even though bilingual legal communication is more frequent nowadays, systematic production of bilingual transcripts of such communication is still relatively rare in the world. And even when transcripts are produced, gaining access to the data can be very hard and can depend on data protection restrictions and the laws of a specific country. The data may have to be anonymised at source, which is extremely costly and laborious. One example of good practice can be found in the United States, where bilingual verbatim police transcripts are available, while most countries rarely make any written transcripts, let alone bilingual ones. The reason is that transcript production is cost prohibitive and it may be reserved for special, major and important cases. Even in the United States the production of police transcripts may not be of equal professional standard across all jurisdictions and court transcripts there are still monolingual only. However, the state of affairs in the US in this respect is much more advanced than anywhere else. For instance, Filipović (2007a, 2013a) studied Spanish-English bilingual transcripts collected in the state of California. She notes that police transcripts in the US seem to be regularly produced as bilingual verbatim documents for interviews with nonEnglish speaking subjects, and crucially, police interview transcripts are additionally checked and translated post-interview by an independent translator (different from the one present in the original interview). In this way, the quality control of police interview transcripts is impressive and the quality of the service is very high. This can 
serve as an example of good practice for others to follow. The control translator has the opportunity to correct interpreting errors or clarify the use of certain words or expressions.

In the UK written police transcripts are monolingual, if produced at all, and bilingual transcripts are rarely available (see Kredens and Morris 2010 for a discussion on transcript production). Thus, doing research in this field is hampered by the difficulty in obtaining datasets. However, both academics and professionals are starting to see the mutual benefit of joint research projects and partnerships that can be formed leading to successful data collection and analysis. This kind of joint collaborative projects that brings together academic researchers and all the professionals involved (i.e. police officers and interpreters) are mutually beneficial, because they lead to both academic and professioanl advances (see also Lai and Mulayim 2014 for a similar point regarding recommendations for joint training of police officers and interpreters). One such example of collaboration is our research project TACIT (Translation and Commnication in Training), which includes authentic data collection and recommendations for professional practice based on the analysis (see section 4).

The related area of court interpreting research needs to be mentioned here because it offers important findings regarding the language of bilingual legal exchanges (e.g. Berk-Seligson 1990, 2009; Mikkelson 2017 [2000]; Hale 2004; Hayes and Hale 2010), which are also valid in police communication in multilingual contexts. Lai and Mulayim observe (2014: 310) that "existing literature on legal interpreting largely concentrates on the courtroom setting" and that this is because of "the comparative accessibility of court trials and transcripts to, for example, interpreter-assisted police interviews which are held close-door". Both domains of research into legal interpreting and interpreter-assisted communication are really two sides of the same coin. Although there are differences between court and police communication (e.g. in institutional and procedural regulations of how the communication is conducted as well as in register and discourse characteristics) both contexts require the same approach when it comes to interpreting, nameley the one essentially guided by precison in terms of both meaning and function. Therefore, both study domains, of court and of police interpreting, are extremely informative for each other.

There have been numerous studies of translating and interpreting in legal contexts in general and in police communication in particular (see Mulayim, Lai and Norma 2015 for a list of references and resources). Most notably, the seminal work of Susan Berk-Seligson identified and addressed a number of relevant issues that are related to translation and interpreting in legal contexts, for example in a bilingual courtroom (e.g. Berk-Seligson 1990) and in bilingual police interviews with officers acting as interpreters (e.g. Berk-Seligson 2009; see also on the same topic Abad 
Vergara and Filipović, forthcoming). Berk-Seligson (1990) lists a number of features that characterise court interpreting (e.g. hedges, insertions, hesitations, etc.) and that are, interestingly, problematic in two ways. Namely, they are the ones most frequently omitted in translation even though they are not given in the original while also being the most frequently added ones in the translation when not present in the original speech. These features underlie the perception of witness testimony style as either powerful or powerless and as a result we may get a powerful testimony in the original (e.g. not ridden with hesitations) that is rendered in a powerless style (with hesitations) in translation. This in turn may lead to the perception of witness as less reliable or trustworthy. Even though this study is of courtroom intepreting we can see how relevant it would be if applied to police contexts of communication.

In fact, a study by Krouglov (1999) has observed somewhat similar phenomena in a police interview context. He analysed interviews with Russian witnesses conducted at a police station by English speaking detectives and interpreted by four different interpreters. Krouglov (1999) found that interpreters often avoided or changed colloquialisms and hedges, which could provide evidence of pragmatic intention. They also tended to introduce more polite forms, which in turn can make the testimony of a witness either less certain or more definite, depending on the specific situation. For instance, on some occasions, when interpreters were short of time or aimed for a concise translation for whatever reason, they often omitted politeness forms, assuming that the meaning of the original is preserved regardless. On some other occasions, the interpreters tended to add politeness forms, especially when interpreting from Russian into English on the assumption that English speakers are generally 'more polite' based on the familiar sets of rules of conduct in the English society. Krouglov (1999: 294) notes that "it is possible that interpreters who introduce additional politeness forms or omit them in their interpretation misrepresent the illocutionary force of the client's utterances, a particularly important issue in the context of a police investigation".

In her study of interrogations involving suspects whose first language is not English and police officers who have a rudimentary knowledge of Spanish, Berk-Seligson (2009) showed how communication difficulties arise from suspects' limited proficiency in English and police officers' equally limited proficiency in Spanish, adding to the officers' inability to adhere to strict ethical rules of interpreter impartiality. Access to justice is shown to be endangered in such cases. In the law enforcement context, the importance of having an interpreter who is neutral and accurate when rendering the information into the target language is of supreme relevance, because the life of "a suspect [...] may depend on what he is understood as having said" (Berk-Seligson 2011: 30) at the investigative stage. Further evidence in a similar vein comes from a case study based on authentic US data by Abad Vergara and Filipović (forthcoming). 
The authors draw attention to the ways in which both linguistic accuracies and the lack of impartiality on the part of the interpreting officer could contribute to blame attribution and lack of neutrality required for the interpreter as a result of the interpreter's dual role (i.e. interpreter and police officer). Kredens and Morris (2010) also provide a number of examples and a discussion of issues that arise in relation to inappropriate and unprofessional interpreting, a well as different practices of sourcing interpreters and ensuring quality of service.

We can conclude here that studying interpreting in police contexts is of fundamental importance not only for the field of forensic linguistics but for the more general goal of achiving equality in access to justice. The studies so far have provided ample illustration that non-native speakers tend to be in a disadvantageous position from the very start, first in interviews with law enforcement and then further throughout the judicial process in courts, where the original statements they make are never recorded (see Hales and Filipović 2016 for details). The excellent practice of making bilingual transcripts in the United States police interview contexts is extremely helpful for the purpose of revealing the kind of disadvantage that non-native speakers may face and we highlight this point in our analysis of the US datasets (section 4). Further issues stem from the fact that languages differ with respect to the ease vs. difficulty and frequencies with which their speakers express certain meanings. We therefore draw attention here to the ways in which both linguistic inaccuracies and the lack of impartiality on the part of the interpreting professional could contribute to blame attribution and lack of neutrality required (especially in the ethically dubious cases of police officers acting as interpreters as well as using unprofessional interpreters in legal interviews).

In the first original attempt to apply a linguistic typology to an analysis of forensic linguistic texts, Filipović (2007b) accounts for the differences in meaning between the original and translation and addresses the consequences of these differences for the understanding and interpretation of reported events. This study shows that there are indeed potentially serious consequences resulting from the different ways in which typologically different languages package information, which is then re-packaged in translation and transformed as a result. Consequently, the information re-packaged in translation is different in content from the original, and this is shown not to be due to individual capabilities of a specific interpreter but rather to broad linguistic tendencies and habits of language engendered by language typology. We discuss these findings in more detail in section 4, where we present our new data that illustrate the continuity in methodology and empirical approach pionered in Filipović (2007b). The emphasis in our study is therefore on the reasons for, and effects of content changes in translation, rather than on form or style of expression (though changes in form and style also matter as shown in the previous studies discussed in this section) 


\section{Applied Language Typology}

Providing an accurate and efficient transmission of meaning is probably one of the main aims of a legal interpreter. However, despite the efficiency in translation techniques, there are some areas in which this task becomes especially challenging due to cross-linguistic differences in how meaning is encoded or 'packaged' in the source and the target language. Research on typology has shown that there are some semantic domains in which languages differ with regard to the encoding of semantic components, its frequency and salience in the rhetorical styles of their speakers. The semantic domain of motion is one of the most prolific areas in which these typological differences have been identified. We will show how this semantic typology can be successfully applied to forensic linguistic contexts. The results on motion events can be an illustration of how Applied Language Typology works, since this analysis can be expanded to other domains in future research (see Filipović 2017a, 2017b).

The framework of Applied Language Typology (henceforth ALT) brings together a variety of descriptive and theoretical findings from areas of the language sciences that are concerned ultimately with language typology and language contrasts. ALT identifies the ways of applying such findings and integrating them into professional practice. The primary focus is the similarities and differences between individual languages and language groups that have a direct impact on language and communication activities, such as acquisition, processing, translation and multilingual communication in different professional contexts. Language typology traditionally groups languages according to grammatical features at different levels of analysis (morphological, syntactic, semantic). Applied language typology sets up contrastive frameworks based on these features, which help us identify when and how various facilitating or impeding factors will impact professional contexts. These practical features of language in use may vary from context to context (e.g. language learning, translation, etc.), but we argue that all applications will benefit from a clear and general classification scheme that identifies the precise points of contrast between languages.

ALT helps us identify certain general criteria that we can use in order to detect those language contrasts that can potentially result in practical difficulty, regardless of the particular area of morphosyntax or lexicon in which they originate. Not all differences between two languages would automatically lead to communication or translation problems. Filipović (2017a, b) lists the following three general types of contrasts between languages that appear to be centrally important for a number of applied domains:

a. The presence vs. absence of a category (morphosyntax or lexicon) in two or more contrasted languages (e.g. evidentials are found in Turkish, but not in 
English; agentivity distinctions in Spanish caused motion constructions, but not in English; see section 4.2.)

b. More restrictive vs. less restrictive category (morphosyntax or lexicon) that is present in two (or more) contrasted languages (for example, colour terms)

c. Complementarity relations in concept or event lexicalisation (whereby the same or similar concept is expressed using different patterns available in two or more contrasted languages; for example nominative/accusative vs. ergative/absolutive case marking, or Path-verb vs. Manner-verb motion event lexicalisations)

In this paper, we illustrate all three criteria using the domains in which the two languages do not share a semantic distinction (agentivity specification in Spanish but not in English verbs), they have different restrictions when it comes to categories (e.g. deictic centres in the expression of deixis in Spanish and Portuguese vs. English) and they have complementary lexicalisation patterns for the same cognitive domain (i.e. path in the verb in Spanish and Portuguese vs. path out of the verb in English in motion event lexicalisation). We discuss and exemplify all these cases in turn, after the outline of the relevant theoretical background.

\subsection{Motion events typology}

Talmy $(1991,2000)$ put forward the original proposal of a typological classification of languages according to how motion is encoded. He identified four obligatory semantic components of motion: Figure, which is the entity that moves; Path, the trajectory and directionality of the movement; Ground, the place where motion takes place; and Motion itself. There are also two co-events that are not compulsory, Cause of motion and Manner of motion. For example in a sentence like (1), the woman is the Figure and the stairs is the Ground. Motion and Manner are encoded in the main verb walked and Path is lexicalised in $u p$.

(1) The woman walked up the stairs

Languages differ in how these components are distributed and expressed and can be grouped in two main groups. Satellite-framed languages codify Path outside the main verb in a peripheral element that Talmy defines as satellite ${ }^{1}$, e.g. English go

1 We use the verb-satellite framed terminology in this paper because it has been adopted and widely used in the field. We note however a number of issues with these labels, which has also been pointed out by many scholars on numerous previous occasions (see Filipović and Ibarretxe-Antuñano 2015 for a detailed account and discussion). A 
out. Verb-framed languages, on the other hand, encode the semantic component of Path (including the trajectory, directionality, etc.) in the main verb. This is the case of most Romance languages, e.g. Spanish salir 'exit'. The fact that Path is mainly encoded outside the main verb in satellite-framed languages allows their speakers to encode Manner more often (e.g. run out, dash out, walk out), whereas verb-framed languages normally encode it in a peripheral element (a gerund, an adverbial phrase, etc.) only when this component is relevant in discourse, e.g. salir corriendo 'exit running', salir muy rápido 'exit very quickly', salir andando 'exit walking'. It is important to note that Talmy argues that the belonging of a given language to one typological group or the other depends on its most characteristic and frequent pattern. In other words, these are the most frequent patterns in English and Spanish, but this does not mean that they are the only ones that are used in the language.

Slobin $(1991,1996 a, 1996 b, 2000,2004)$ has studied the implications of this typology for discourse, translation and language acquisition, as an illustration that supports his Thinking for Speaking hypothesis. His research combines different methodologies (e.g. child language acquisition as in the studies collected in Berman and Slobin 1994) and translation (Slobin 1996b) to show that satellite-framed language speakers tend to have a wider Manner verbs lexicon, e.g. dash, mosey, tiptoe, jog, trudge, stomp, prance, etc. They describe more the trajectories in Ground elements while verbframed language speakers leave Path to be inferred and they produce more cases of Complex Path with the expression of the origin and the goal of the movement. For example, a typical description in English would be: The deer tips him off over the cliff into the water, whereas in Spanish a typical description would be Lo tiró. Por suerte, abajo habia un rio 'He threw him. Luckily, below, was the river' (examples taken from Slobin 1996b: 202-204). Finally, satellite-framed languages tend to provide more dynamic descriptions than verb-framed-language speakers who usually provide more static descriptions.

The work by Talmy and Slobin has inspired numerous researchers who have tested the claims and largely supported the related proposals with data from several languages (see among others the studies collected in Berman and Slobin 1994, in Strömqvist and Verhoeven 2004, and in Ibarretxe-Antuñano 2017). These contributions have also identified some problematic areas that have been refined with different proposals (see Filipović and Ibarretxe-Antuñano 2015 for a detailed account of the main contributions to the typology, the main problematic areas and the proposals that

proposal by Slobin, as articulated in his most recent publication on the topic (Slobin 2017) to label the dichotomy as PIV (path-in-verb) vs. PIN (path-in-nonverb) seems appealing since it captures more generally two key facts about the typology: a) path as the crucial, defining element in a motion event and b) dispenses with the problematic notion and definition of a satellite. 
several authors have formulated to overcome these difficulties). These areas are mainly the problematic definition of satellite (see Filipovic 2007a, Beavers, Levin and Tham 2010); the difficult adscription of languages such as Thai or Chinese, that lead Slobin (2004) to propose a third typological group, that of equipollent-framed languages (see also Zlatev and Yangklang 2004); and the differences between languages that belong to the same typological group. This is the case of Basque, for example, since their speakers detail Path more than other verb-framed languages (Ibarretxe-Antuñano 2004), and also of Serbian, whose speakers tend to provide less Manner information than English speakers on certain occasions due to morphosyntactic restrictions (Filipović 2007a). Verkerk (2013) further confirms this "ambivalence" of Serbian because the lexical diversity documented in the Serbian sample is more comparable to verb-framed languages than satellite-framed with which Serbian has been grouped in the typology. This kind of observations and evidence lead to many authors to consider the typology as a cline rather than a dichotomy (Filipović 1999). Slobin (2004) proposes a Mannersalience cline and Ibarretxe-Antuñano (2009) a Path-salience cline to account for these intra-typological differences. In the next subsections the focus is on research about Manner, Cause and Deixis, three semantic components that turned out to be crucial in our analysis of the interpreting of motion events in forensic linguistic contexts.

\subsubsection{Manner}

Manner is, together with Path, one of the best-studied semantic components of motion. Satellite-framed language speakers tend to encode it very often, despite its optionality. Their Manner verbs lexicon is ampler and includes more fine-grained distinctions. In fact, Slobin (1996a: 459) distinguishes between first tier and second tier Manner verbs. The first group includes very common general Manner verbs, such as run, fly or jump, whereas the latter includes more specific verbs that are not that frequent, such as dash, scramble, etc. Satellite-framed languages exhibit a vast lexicon of Manner-of-motion verbs, both first and second tier. On the other hand, the number of second-tier Manner verbs in verb-framed languages is limited and their speakers show low frequency of use of the ones that are available. Slobin (1997: 458) shows how Spanish translators of The Hobbit have used fewer Manner verbs to cover Manner of motion. For example they use deslizarse to translate creep, glide, slide, slip and slither; escabullirse for scurry off, scuttle away/off and slip away; saltar for bound, dive, hop, jump, leap and spring; and tropezar for stumble, trip and tumble.

Slobin $(2004,2006)$ suggests that some factors favour the characteristic encoding of Manner in these languages. For example, the possibility of its expression by a finite rather than a non-finite verb form and its encoding in a single morpheme rather than in a phrase or clause (e.g. English tiptoe vs. Spanish ir de puntillas 'walk on the tip of 
the toe') make Manner of motion more accessible to English speakers. In this sense, verb-framed lexicalisation patterns make it harder for speakers to encode motion. The main verb slot is normally filled by a Path verb and therefore Manner is encoded in a non-finite verb, such as a gerund. The boundary-crossing constraint in verb-framed languages does not help either. This phenomenon, first noted by Aske (1989), received its name by Slobin and Hoiting (1994). This constraint impedes the use of Manner verbs in events that imply the crossing of a boundary. For example, we can see in (2) that a Manner verb can be used in these contexts in English.

(2) He danced into the living-room

However, in Spanish this seems more complicated. A sentence like (3) does not imply the crossing of the boundary but rather that the person danced until she reached the boundary of the living room. Example (4) is not a better solution, since the preposition en 'in' introduces a locative complement. The meaning of the sentence then receives a locative interpretation.

(3) Bailó al salón

dance.3SG.PST to.the living-room

'S/he danced to the living-room'

(4) Bailó dance.3SG.PST in the living-room

'S/he danced in the living-room'

The best solution to convey the meaning of (2) into Spanish is the sentence presented in (5). In this case the main verb is necessarily a Path verb and Manner has to be encoded in a gerund:
(5) Entró
al salón
bailando
Enter.3sG.PST to.the living-room dance.GER
'She entered the living-room dancing'

The degree to which this restriction is followed in Romance languages has created some debate among scholars (see among others Martínez-Vázquez 2013, Iacobini and Fagard 2011, Pedersen 2014). However, it seems clear that this constraint does 
not apply in satellite-framed languages and that it is very common in verb-framed languages, with different degrees of application depending on the language and the type of event.

Several studies have shown the cognitive effects of these differences in the accessibility to encode Manner in both types of languages. Slobin (2006) asked speakers of English and Spanish to retell a story, part of a novel, with rich descriptions in motion. Spanish speakers focused on the physical surroundings of the scene and did not mention Manner of motion, while English speakers used Manner of motion verbs in their descriptions. Psycholinguistic experiments have also showed the clear preference for Manner by English speakers and for Path by Spanish speakers. Naigles and Terrazas (1998), for example, studied how speakers of these two languages interpret novel motion verbs. As expected, English speakers give a Manner interpretation and Spanish speakers consider them Path verbs. Other psycholinguistic researchers have focused on the linguistic effects of this contrast in memory (Filipović 2010a, 2010b, Filipović and Geva 2012). They conclude that there are no effects under normal conditions, i.e. speakers of both languages remember Manner equally. However, linguistic effects on memory show when a heavier memory load is involved. In other words, when participants had more elements to remember and the task was more complex, English speakers remembered Manner better than Spanish speakers. In the case of bilingual speakers (Filipovic 2011) they were in an intermediate position with regard to linguistic effects. Interestingly enough, they remembered better than Spanish monolinguals but worse than English monolinguals. This is therefore a stark difference between languages from both groups of the semantic typology. As we will see below, this will have important implications for the professional task of legal interpreters.

\subsubsection{Cause}

An important stream of research on motion event typology has focused on caused motion events (see Hendriks, Hickmann and Demagny 2008, Hickmann and Hendriks 2010, among others) and in a special subset of these events, that of placement and removal events (see the studies collected in Kopecka and Narasimham 2012). In these cases the Figure moves to a different location because of an external agent that generates the movement. As in the case of voluntary motion, there is crosslinguistic variation in how semantic components are encoded. Ibarretxe-Antuñano (2012) argues that two semantic components are crucial in Spanish: intentionality and force dynamics, as she illustrates with this continuum combining both factors (Ibarretxe-Antuñano 2012: 138-139): 
(6) a. Se cae el libro

CL.3 fall.3SG.PRE the book

'The book falls'

b. Se le cae el libro

CL.3 DAT.3SG fall.3SG.PRE the book

Lit. 'The book falls to him'

'He drops the book unintentionally'

c. Deja caer el libro

allow.3SG.PRE fall.INF the book

Lit. 'He allows the book to fall'

'He drops the book intentionally but softly'

d. Tira el libro

throw.3SG.PRE the book

'She throws the book (intentionally)'

e. Lanza el libro

throw.3SG.PRE.away the book

'He throws the book away'

f. Arroja el libro

throw.3SG.PRE.away.violently the book

'She throws the book away violently'

These examples show how intentionality and force dynamics increase from (6a) to (6f). Intentionality is completely absent in (6a), as there is no external agent. In (6b) the agent does not show intentionality, while it does in all the other cases. Force 
dynamics increases from weaker into stronger and more violent from (6d) to (6e) and (6f). The construction in (6b) is of special interest, since in English it would be normally translated with the verb drop, exactly the same as (6c) in which the intention of the agent is clearly marked (See also Berk-Seligson 1983 on this construction). Filipović (2007b) shows that indeed the translation of se me cayó as drop is ambiguous. She finds that in a police interview in California the suspect is asked as many as nine times whether the victim fell on the stairs or whether the suspect dropped her. The translation provided by the interpreter felt inaccurate and ambiguous to the police officer and this was not due to lack of professional practice but to the fact that English does not have an easy way to encode this involvement with lack of intentionality that is so frequently expressed with this Spanish construction. In fact, psycholinguistic work has explored the effects on memory of these differences between Spanish and English (Fausey and Boroditsky 2011, Filipović 2013a). For example, Filipović's (2013a) results show that when asked to remember whether people in short video clips were acting on purpose or not, Spanish speakers consistently remembered intentionality of the agent, even while speaking English. English speakers performed worse in this task and did not remember the intentionality in these events. Therefore, it seems clear that the encoding of motion and its correct translation is as challenging as crucial for forensic linguistics. It will be one of the main areas of our analysis and more examples will be provided in section 4 .

\subsubsection{Deixis}

Deixis is another area in which English on the one hand and Spanish and Portuguese on the other differ in how they encode meaning. In Talmy's typology, Deixis is considered a subcomponent of Path, although other scholars highlight its relevance in some languages where it has its own specific slot (see Choi and Bowerman 1991 for Korean, and Matsumoto, Akita and Takahashi 2017 for Japanese and Thai). Deictic motion verbs in English have been studied extensively (Fillmore 1971). From a cross-linguistic perspective, Gathercole $(1977,1978)$ explains that there are different ways in which deixis is encoded. The main difference lies on who can take the role of deictic centre. In English both speaker and addressee can act as the deictic centre. This means that venitive verbs such as come and bring can encode motion towards the speaker and towards the addressee. This also happens in German, French and Italian, just to name a few languages. In Spanish and Portuguese the speaker is the only entity that can take the role of deictic centre. Other languages like Japanese and Thai share this feature. The equivalent verbs in Spanish venir 'come' and traer 'bring' and Portuguese vir 'come' and trazer 'bring' will only encode motion towards the speaker, as showed in a phone conversation in (7): 


(7) - iVienes mi casa?
come.2sG.Pre to hy house
'Are you coming to my house?'
-Vale, ahora voy
ok, now go.1sG.PRE
'Ok, I'm coming now'
-Vale, ahora *vengo
ok, now come.1sG.PRE

In this case, English speakers would prefer the use of come to indicate motion towards the addressee. However, the use of venir or vir in this context would sound unnatural or confusing to Spanish and Portuguese speakers. The only exceptions that Gathercole $(1977,1978)$ finds for the use of venir in motion that is not towards the speaker are cases of extended deixis, i.e. when deictic verbs are used but the deictic centre is not at the goal of motion at the time of the utterance. For Spanish venir 'come', Gathercole finds two possible uses. First, when the speaker identifies with the place, in cases like (8):

(8) ¿Viene Maria al cine esta noche? come.2sG.PRE María to.the cinema this night?

'Is María coming to the cinema tonight?'

In these cases, the use of venir implies that the goal of motion is a familiar place for the speaker (for example as a workplace) or that the speaker will be at this place as well. Second, venir can also be used in an accompaniment context. These are cases like (9):

(9)

¿Quieres venir al teatro (conmigo)?

want.2SG.PRE come.INF to.the theatre (with.me)?

'Do you want to come to the theatre (with me)?

According to Gathercole the use of ir 'go' instead of venir 'come' would be possible in (9) but it would mark some degree of distance or lack of intimacy. As can be noted 
these differences in the use of deictic verbs do not match the limits of verb-framed or satellite-framed languages. They also differ within genetic families, at least in the case of Romance families. The use of these verbs is problematic for speakers of Spanish as a second language and this is a domain prone to transfer from the first language, as noted by Lewandowski (2014) for Polish speakers and Hijazo-Gascón (2017) for French, German and Italian speakers.

Although it is not the case of the languages studied in this article, it is worth explaining that some languages have specific forms to encode deixis. For example, in Serbian, the prefixes o(d)- 'from the speaker' and do- 'to the speaker' are added to motion verbs and make deixis more salient (see Filipović 2007a). This allows the listener to identify where the speaker was at the time, as for example in (10) and (11):

(10) Otrcao

from-the-speaker/scene.ran.PST-3SG-M

'He ran up the stairs'

(11) Doretutala

to-the-speaker/scene.stagger.PST-3SG-M

'She staggered and said hello' je

be-cop

up stairs

se $\quad$ rekla zdravo

REFL and said hello

Similar linguistic elements are used in Japanese (Matsumoto, Akita and Takahashi 2017) and German (Bamberg 1994). These devices present a complex difficulty for language learners (see Yoshinari 2015 for learners of Japanese and Liste-Lamas 2015 for learners of German). The translation from languages that have specific devices to encode deixis into languages that do not have specific elements normally ends up with the omission of this information, as in the English translations of (10) and (11), which can be crucial in forensic contexts.

\subsection{Applying motion typology}

Motion events typology has been applied to several areas of applied linguistics. For example, there is a vast literature on motion events in second language acquisition (see Ellis and Cadierno 2009, Han and Cadierno 2010 and Cadierno 2017 for an overview). These studies explore the possibilities of restructuring lexicalisation patterns and thinking for speaking in a second language. The field of translation has been at the heart of the typology, since Slobin has supported his theoretical claims with data 
gathered from translations (Slobin 1996b, 1997, Slobin 2005, among others). Other authors have been inspired by his work in translation of motion and have expanded the range of languages under study and identified several translation techniques (see Ibarretxe-Antuñano 2003 on English into Basque, Cifuentes-Férez 2006 for English into Spanish, Cerdá 2010 on Spanish into English and Molés-Cases 2016 for German into Spanish). A summary of translation techniques on motion has been proposed in Ibarretxe-Antuñano and Filipović (2013), including the addition of Path and/or Manner, its omission or its substitution or modification by other more or less specific semantic components.

Filipović (2017a, 2017b) defines the term Applied Language Typology as the study of typological effects that impact successful communication, learning and professional practice. Therefore, it also includes other areas different from interpreting, such as language acquisition and communication in professional contexts. In the case of interpreting, our main focus in this paper, she gives examples of how morphosyntactic and semantic typologies can pose challenges for professional translators and interpreters. This term is of special interest to our research since it allows us to account for the difficulties interpreters find to convey meaning in the forensic context of interpreter-mediated police interviews.

In the research presented here, the above-mentioned contrasts on Manner, Cause and Deixis will prove to have important consequences for the professional practice of legal interpreters. Legal interpreters are faced to crucial decisions in very short amounts of time. When the source and the target language present typological differences of this type, the decision is whether to provide a translation that is closer to the source but probably awkward or not natural in the target language or to prioritise the rhetorical style and naturalness in the target language, with the risk of omitting or modifying semantic information that can be crucial for the on-going investigation.

\section{Current Research: Applied Language Typology in Police Interviews}

The data presented in this paper are part of research in progress within the project entitled Translation and Communication in Training (TACIT) at the University of East Anglia (United Kingdom). This project aims at identifying potential difficulties in translation and communication in a forensic context and at suggesting ideas to overcome these problems. Our corpus consists of two large datasets of police interview transcripts in California (USA) and in Norfolk (United Kingdom). This corpus is analysed from different linguistic perspectives, such as empathy, pragmatic directness 
and indirectness, complexity of legal language, etc., being Applied Language Typology one of the main approaches to data analysis.

The results presented in the next section are part of the analysis of three bilingual Spanish-English transcripts of police interviews in California (over 73,900 words) and the analysis of 3 audio recordings of police interviews with a Portuguese-English interpreter in Norfolk (47,000 words). Spanish and Portuguese present interesting typological differences with English, as explained in the previous sections. Therefore, the examples below will illustrate the relevance of Applied Language Typology in the field of Forensic Linguistics.

One of the main differences between the American and the British transcripts is that the former are bilingual and the latter are monolingual. There is also a section in the US transcripts that contains a parallel, often more literal, control translation. The translations by both interpreters do not always coincide. In several cases this lack of coincidence is related to the typological differences that are difficult to overcome, as we saw in previous section. In the examples coming from the American transcripts we will use S for Suspect, P for Police Officer, I for interpreter and CI for control interpreter. British transcripts do not transcribe the interviews in both languages. Although the interview is conducted with an interpreter, the written version of the interview is exclusively in English. Data from Portuguese are therefore directly elicited from the oral recordings and the recordings are contrasted with the monolingual transcript available.

In this section the results from the analysis of these transcripts will be provided. As a satellite-framed language, English presents interesting contrasts in the expression of motion with Spanish and Portuguese, which are verb-framed languages. These typological differences pose different challenges to the interpreters, depending on whether the source language has more or fewer categories than the target language in that particular domain. In other cases the same categories work differently, which poses another difficulty to the interpreters. The results are organised here according to the different challenges to the interpreter. We look at a sample of bilingual police interviews with suspects in order to identify what kinds of contrasts based on typological differences between English and Spanish or Portuguese may cause misunderstandings between interlocutors or misrepresentation of claims. We focus on recurrent problems that are exemplified across a number of cases, in different transcripts with different interpreters, in both the UK and the US. By doing so, we aim to highlight how linguistic typology can be applied in a forensic linguistic context. Previous research has not engaged in such an approach to the analysis of police interviews and our goal here is to demonstrate the benefits of such an approach for our understanding of real life consequences of language differences in sensitive social contexts. An important 
point we want to emphasise is that our approach enables us to detect and explain interpreting difficulties that are not due to individual interpreters' performance but rather pertain to broader typological contrasts that even otherwise very competent professional interpreters struggle with it. This provides a template for the study of any language combinations in any communicative context that involved interpreting (e.g. medical, business, social services, educational, etc.).

\subsection{Interpreting from fewer to more categories: Adding Manner}

In some cases the source language presents fewer categories than the target language, for example Manner verbs. The interpreter will need to decide in these cases whether to add information to meet the rhetorical style of the target language or to keep fewer categories of the source language and sound less natural in the second language. This is the case of Manner of motion. As previously explained, satellite-framed languages present a wider array of Manner verbs. While languages like English have more finer-grained Manner distinctions encoded in their second tier verbs, e.g. dash, prance, mosey, verb-framed languages tend not to present many second tier Manner verbs and their Manner lexicon is less varied and more general. This has consequences in the rhetorical style of both languages. English speakers are used to including frequent Manner of motion details in their descriptions of motion. A translation without Manner of motion can feel unnatural to the English listener, and the interpreter might feel the need to add Manner information to render a more natural translation.

In our transcripts we find several examples of this challenge for the interpreter. In (12), the original sentence in Spanish does not include any Manner information, which is usual in a verb-framed language:

(12) S: Subi para arriba

$$
\text { ascend.1sG.PST to up }
$$

I: $\quad$ I ran upsta... I walked upstairs

CI: I went upstairs

We can see how this clashes with the typical rhetorical style in English and the interpreter feels the need to add Manner information, in fact he tries first with run and then modulates this Manner information with walk. Probably a literal translation like 'I went upstairs', provided by the control interpreter, or 'I ascended upstairs' does not sound natural enough to English-speakers. However, in the Spanish translation 
it is impossible to infer the speed with which the person was going up the stairs. Therefore, the interpreter is unconsciously adding information that can make police officers create an image of the crime scene that does not necessarily correspond with the testimony of the speaker.

A similar example can be found in (13). In this case the notion expressed is not voluntary motion but caused motion.

(13) S: $\quad$...porque la llevaba de aquí

...because her.ACC take.PST.1sG from here

I: $\quad$...because when I was dragging her

CI: $\quad$... because I was holding her

In this case the interpreter is adding Manner by using the verb drag, which implies force dynamics and a heavier victim, suggesting opposition or unconsciousness of the person that is being moved. This is not implied in the original llevar, which is a much more neutral verb, usually translated as 'take'. The use of drag could be explained by the communicative context that made the interpreter infer that this was the way the suspect was carrying the victim. However, this is not what the person said in Spanish.

Further examples that reflect crosslinguistic differences as sources of misunderstanding or misinterpretation can also found in the British police interview data. For instance, here we also detect the typological feature of adding manner in translation from a verb-framed (Portuguese) into a satellite-framed language (English). The more neutral verb escapar 'escape' gets translated as 'run off and the phrase descer do carro 'descend from the car' is translated as 'jump out of the car'. The descriptions of the situations appear much less dynamic in the original Portuguese descriptions than in the English translation, the implications of which can be significant for the understanding of how events unfolded (as was also noticed before; e.g. see Filipović 2007b; Ibarretxe-Antuñano and Filipović 2013; Hales and Filipović 2016; see also Filipović in preparation). This is particularly relevant for the cases of sexual assault and domestic violence where these examples come from, whereby the intensity conveyed in language conditions and the conceptualisation of the intensity of violence involved in the offence (Filipović, in preparation; see also Ibarrexte-Antuñano and Filipović 2013 for more details on this topic). 


\subsection{Interpreting from more to fewer categories: Losing Intentionality}

There are other cases in which the interpreter finds more categories in the source language than in the target language. As explained above, caused motion in Spanish can present several degrees of encoding (Berk-Seligson 1983, Ibarretxe-Antuñano 2012, Filipović 2013). Force dynamics and intentionality are found to be the main semantic components that consistently intervene in this encoding. As noted above, these variants are normally translated into English as drop, which is ambiguous with regard to these semantic components. A clear example is (14) cited in Filipović (2007b: 262)

(14) P: Okay, You said before that she fell or you dropped her on the stairs?

I: ¿ ¿Usted les dijo antes de que ella se cayó o la botó en las gradas?

you.FORM them say.2SG.PST.FORM before of that she REFL

fall.3sG..PST or her throw.2sG.FORM.PST in the stairs?

S: $\quad$ Sí, sí, se me cayó

yes, yes, REFL me fall.3sG.PST

I: $\quad$ Yes, I dropped her

However, the very same Spanish construction se me cayó can be also translated as (15) as it shows in our data. In this case the interpreter has chosen a non-intentional translation, and he uses she fell instead of drop. With this option there is no ambiguity but the involvement of the speaker marked with the Spanish me 'to me' is completely omitted, leaving out of translation information that could be crucial. Probably the most accurate translation would be the use of a paraphrase like 'It happened to me that she fell', but this is a too long sentence difficult to elaborate in the time pressures and context of this interpretation ${ }^{2}$.

$$
\text { S: } \quad \text { Y dos veces que se me cayó en las gradas }
$$

And two times that she REFL me fall.3sG.PST in the steps

2 Probably 'She happened to fall' is a more grammatically correct translation, as suggested by one of the reviewers. However, we would like to point out: (a) that the paraphrasis including all the information conveyed in Spanish sounds unnatural in English, and (b) that the speaker includes himself in the action (with se me 'to me') in the Spanish sentence. She happened to fall would mean that the person speaking (he) was not involved and this is not the case. In other words, she was not the accidental agent, but an unconscious patient. 
I: $\quad$ that she fell on the stairs

CI: $\quad$ and two times when I dropped her on the steps

In fact, the (non-)expression of the agent can be problematic in other ways. In English indirect communication tends to be prevalent and the passive voice is widely used across communicative situations. This explains the question posed by the police officer phrased as in (16). A literal translation of this sentence would sound awkward and confusing in Spanish. The interpreter opts for a more idiomatic Spanish translation in which it is clear that the police officer is asking this person if he was the person who moved the object in question (a jacket):

(16) P: Did that go over the fence or did that get into the garbage can?

I: $\quad$ Y eso lo tiró al otro lado de la fensa o lo puso en la basura

And this it throw.PST.2sG.FORM to.the other side of the fence or it put.pst.2sG.FORM in the garbage

'And this, did you throw it to the other side of the fence or did you put it into the garbage bin'

The interpreter is here disambiguating an ambiguous source language sentence. On top of that she has to decide whether to use a formal or an informal treatment of the addressee in the question formulated by the police officer. The formal and informal distinction between Spanish pronouns tú 'you informal' and usted 'you formal' is a category not present in English. Even though the formal pronoun usted is not explicitly mentioned, the verb conjugation corresponds to this formal way of addressing ${ }^{3}$. This could somehow 'compensate' and add some sort of the indirectness present in the source text although in a more general manner as the interpreter should be consistent with formal treatment throughout the interview. The changes in the expression and foregrounding (or not) of the agent and her intentionality by means of active, middle and passive voices seem to be one of the most frequent interventions of interpreters in this Californian corpus. Interpreters' translations show differences with the control interpreters' versions when dealing with these constructions (HijazoGascón in preparation).

3 Both suspect and interpreter seem to speak Mexican Spanish, according to other linguistic features in their speech (e.g. lexical choices). In this variety the tú (informal) vs. usted (formal) distinction is kept for the second person singular pronouns. It is lost, however, in the second person plural. In this case ustedes is used for both formal and informal contexts, as happens in the other Latin American varieties, as well as in the Canary Islands and some varieties in the South of Spain. 
In another example found in the British transcript data we see a similar problem with the English verb drop. The police officer in the original question did not specify the intentionality of the meaning of that verb while the Portuguese interpreter had to choose either intentional or non-intentional meaning in translation because the equivalently unspecified verb or construction is not available in Portuguese. He chose the intentional meaning and provided the phrase dexar cair 'let fall' in Portuguese ${ }^{4}$. The suspect was obviously trying to explain that there was no intentionality involved and that the eggs were not dropped at all but were placed on the floor. Furthermore, this attempt to clarify what happened with the eggs left the information introduced in the question about the victim's attempt to escape unaddressed. This is a very important omission because the suspect was claiming throughout the interview that the alleged victim (his girlfriend) was staying with him willingly and according to him no attempts to escape were being made (see Filipović, in preparation for further discussion). The manner of motion, running, is also absent from the translation of the officer's original question, expected in the context of the typological distinctions between English and Portuguese:

(17) P: $\quad$...she managed to run off and as she ran off she dropped her carrier bag with the eggs in.

I: $\quad$...ela arranjou a maneira de fugir em direção à casa deixou cair o saco con os ovos.

S [through I]: She said careful with the eggs because the eggs were on the floor, don't step on it.

This example illustrates numerous difficulties in interpreter-assisted police interviews. It also shows the importance of studying typological differences and focusing on precision in rendering all the pieces of information from one language into the other. Unresolved ambiguity as well as missing or adding information can have serious real-life consequences that go beyond the mere misunderstanding. They can sway judgement and result in more severe punishment (see Ibarretxe-Antuñano

4 The non-intentional choice in Portuguese would have been the equivalent of $\chi$ fell $(\chi$ caiu $)$ but then the agent would have been left unexpressed. Crucially, unlike Spanish, Portuguese does not have middle voice (the equivalence of se (me) cayó), which clearly expresses all the event components in accidental events, the nonintentional agent, the action and the object. In this case, the interpreter chose the closest option to the English construction (with a coincidence of the agent and the syntactic subject). By doing this, the interpreter opts for the intentional meaning of drop and excludes its non-intentional meaning. We believe that it is fundamental to highlight such language contrasts, and integrate them into L2 pedagogy. 
and Filipović 2013; Filipović and Ibarretxe-Antunano 2015; Fausey and Boroditsky 2011).

\subsection{Interpreting categories that work differently: What Deixis tells us}

English, Spanish and Portuguese have the same categories of deictic motion verbs. They all have a venitive voluntary motion verb like come and a causative voluntary motion verb like bring in opposition to the non-venitive go and take. However, as explained above, the differences lie in the use that venitive verbs have in each of these languages. Portuguese and Spanish are more restrictive in the identification of a deictic centre. Only the speaker can receive this function. This differs from English in which both interpreter and addressee can take this role. Therefore, come and bring can indicate motion towards the person who is speaking and towards the person who is listening. However, Spanish and Portuguese venir/vir 'come' and traer/trazer 'bring' clearly indicate motion only towards the speaker and never towards the addressee. This means that Spanish and Portuguese speakers are less ambiguous than English speakers when using their come and bring equivalents, as the movement can refer only to places where the speaker is at the moment of the utterance or places with a strong identification with the speaker (e.g. her home).

In (18) we can see an example of the use of traer in Spanish and its translation into English with pick. The sentence clearly indicates that the man always brought the children back to the family home (where the speaker is at the moment of the utterance). The interpreter uses pick $u p$ in English, which does not imply any endpoint of movement. A Spanish speaker listening to the source testimony would infer that the movement of the man is to go to the kindergarten and take the children back to the family home, the English-speaking listener to the translation would not necessarily infer this. Picking the children up does not necessarily imply taking them to the family home.

(18) S: $\quad$ Es que solo, solamente él casi no los cuidaba porque, este, los niños pasaban en la Guardería, cuando iban a traer un niño, iban a traer al otro al rato y entonces ya cuando estaban aquí los cuatro entonces estaban juntos.

I: $\quad$ It's just that by himself, he practically didn't take care of them, because, you know, the kids would spend their time at Day Care, when they would go pick $u$ p one child, they would go pick the other one a little bit later and so then once all four were here they'd be together. 
The interpretation of deictic elements always depends on context. However, the rules to interpret this context differ cross-linguistically. When transcripts are used in court trials, this context (pointing gestures, intonation, facial expressions, etc.) is lost and this gives rise to potential misunderstandings. A mistake or an omission of information in the translation can modify the message and leave out information that can be relevant to the people involved in the process and that cannot be compensated with context as in real-life interpretation. This reinforces the importance of having a control interpreter that transcribes bilingual transcripts.

\section{Discussion and conclusions}

The main aim of this paper is to raise awareness on the importance of goodquality interpreting of meaning in Forensic Linguistic contexts. The main contributions of previous literature have been revised and a special focus has been on Applied Language Typology (ALT) (Filipović 2017a, b). Data from the analysis of real transcripts in California (USA) and Norfolk (UK) revealed that the translation of certain semantic components of motion pose a real challenge for English-Spanish and English-Portuguese interpreters. In some cases the interpreter needs to translate from more to fewer categories as in the case of Manner of motion from English into Spanish or Portuguese. This normally results in the addition of Manner information that is not present in the source text in order to meet the rhetorical style requirements of the target text. The opposite situation is found on other occasions, when the interpreter needs to translate from more to fewer categories, as in the case of caused motion from Spanish into English. The lack of an exact equivalent of the reflective passive construction of se me cayó 'it happened to me that it fell' (also possible with other verbs such as se me rompió 'it happened to me that it broke') forces translators to make different decisions. The most common is the use of drop, which renders the meaning ambiguous as it can be interpreted as accidental or non-accidental. However, in some cases the interpreter directly omits the involvement of the speaker in the action, using simply the verb fall. Finally, there are some instances of translations of the same categories that differ in meaning such as deictic motion verbs come, venir and vir and bring, traer and trazer. This area has received less attention and is a promising area for future research.

From a theoretical perspective, our results contribute to other studies applying typology to translation (Slobin 1996b, 2005, Ibarretxe-Antuñano 2003, Cifuentes-Férez 2006, Ibarretxe-Antuñano and Filipović 2013) and in particular to forensic linguistic contexts (Filipović 2007b, 2013, 2017, Rojo and Cifuentes-Férez 2017). In a broader sense, these results also contribute to studies on motion events and the bilingual mind (Filipović 2010a, 2010b, 2011, Filipović and Geva 2012, Ellis and Cadierno 2009, Han and Cadierno 2010, Cadierno 2017, Goschler 2013, Berthele and Stocker 2016, 
Berthele 2017) since they show how interpreters cope with the demanding process of interpreting in both languages under high pressure, in cases in which both languages do not match with equal linguistic elements. In other words, research on bilingual interview exchanges in a legal context leads to fascinating discoveries that not only have immense practical value (i.e. for our understanding of the consequences that may happen if the message from the original is not accurately conveyed in translation) but also they inform our theoretical assumptions about the ways mind processes language and gets affected by it (e.g. when language(s) have effects on memory and judgment; see Filipović 2011, 2013, Ibarretxe-Antuñano and Filipović 2013).

The results presented in this paper show the importance of Applied Language Typology. A good understanding of language contrast between languages can help to enhance the efficiency and accuracy of translations in legal contexts. Typology in general offers a good theoretical base to study the contrasts that appear in different languages, as it focuses on classifying languages according to the morpho-syntactic and semantic features they share regardless of their genetic origin. In the case of the semantic typology of motion presented here, English differs from Spanish and Portuguese following their adscription as satellite-framed and verb-framed languages respectively. Our results show that there are some areas that should be explored further, both from a theoretical and a practical angle. It is the case of contrasts on Manner, Cause and Deixis. This analysis gives examples in real contexts in which these differences are revealed to be crucial and that a mistranslation can lead to important miscommunication, ambiguity, addition and omission of information. Our research also provides a somewhat different insight into police interviews, showing the ways to identify the precise points of conflict in multilingual communication in this highly sensitive context, which, as we have shown, can be traced to some key typological differences between languages.

It is important to note that the conclusions of this research do not undermine the value of the work carried out by legal interpreters. These cross-linguistic differences tend to pass unnoticed, but this should by no means be considered as a lack of care of interpreters in their professional duty. As we have shown, the intepreters may just be following the grammatical and preferred usage patterns in each language. These language contrasts are not easy to detect without specific training in linguistics and both second language and interpreting training tends to overlook semantic differences to focus on other areas of linguistics (morphology and syntax, pragmatics, etc.). Therefore, Applied Language Typology has important implications for the training of language teachers and interpreters. It is important that more attention be paid to these contrasts so that interpreters and control interpreters are aware of the implications that they have for their professional practice. Another important 
implication of this analysis is the use of bilingual transcripts and control interpreters. Although we understand that this practice is not always available due to its high costs, it should be considered for the most sensitive cases. A change of practice in legal systems that do not provide transcripts of interviews of bilingual speakers would be required to achieve a better practice in the translation of meaning in police interviews. A careful revision of transcripts can be crucial for determining the implication of a suspect in a crime. More awareness of issues tackled by forensic linguistics would help to guarantee access to justice for everybody, including non-native speakers in the legal system.

\section{References}

Abad Vergara, S. and L. Filipović (forthcoming). Separating investigation from interpretation: The issue of mixing the investigator and interpreter role in bilingual police interviews.

Aske, J. (1989). Path predicates in English and Spanish: A closer look. Proceedings of the Fifteenth Annual Meeting of the Berkley Linguistics Society 15: 1-14.

Bamberg, M. (1994) Development of Linguistic Forms: German. In R. A. Berman \& D. I. Slobin (eds.) Relating events in narrative. A crosslinguistic developmental study. Hillsdale, NJ: Lawrence Erlbaum Associates. 189-238.

Beavers, J., B. Levin \& S.W.Tham (2010). The typology of motion expressions revisited. Journal of Linguistics 46: 331-377.

Berman, R. A. \& D. I. Slobin (1994). Relating events in narrative: A crosslinguistic developmental study. Hillsdale, NJ: Lawrence Erlbaum Associates.

Berk-Seligson, S. (1983) Sources of variation in Spanish verb construction usage: The active, the dative and the reflexive passive. Journal of Pragmatics 7: 145-168.

..... (1990). The Bilingual Courtroom: Court Interpreters in the Judicial Process. Chicago: University of Chicago Press.

..... (2009). Coerced confessions: The discourse of bilingual police interrogations. Berlin: Walter de Gruyter.

.... (2011) Negotiation and communicative accomodation in bilingual police interrogations: a critical interactional sociolinguistic perspective. International Journal of the Sociology of Language 207: 29-58.

Berthele, R. (2017) When bilinguals forget their manners. Language dominance and motion event descriptions in French and German. Vigo International Journal of Applied Linguistics 14: 39-70. 
Berthele, R. \& Stocker, L. (2016) The effect of language mode on motion event descriptions in German-French bilinguals. Language and Cognition: 1-20 doi:10.1017/ langcog.2016.34

Cadierno, T. (2017). Thinking for speaking about motion in a second language. Looking back and forward. In I. Ibarretxe-Antuñano (ed.) Motion and Space across Languages. Theory and Applications. Amsterdam: John Benjamins. 279-300.

Choi, S. \& Bowerman, M. (1991) Learning to express motion events in English and Korean: The influence of language-specific lexicalization patterns. Cognition 41(13): $83-121$.

Cifuentes-Férez, P. (2006). La expresión de los dominios de movimiento y visión en inglés y en español desde la perspectiva de la lingüistica cognitiva. Unpublished master's thesis, Universidad de Murcia, Spain.

Cerdá, J. P. (2010) Estrategias utilizadas en la traducción inversa españolinglés de verbos de movimiento: un estudio en lingüistica cognitiva. Unpublished master's thesis, Universidad de Concepción, Chile.

Coulthard, M., \& Johnson, A. (2007). An introduction to forensic linguistics: Language in Evidence. New York, NY: Routledge.

Coulthard, M. \& A. Johnson (eds.). (2010). The Routledge Handbook of Forensic Linguistics. London: Routledge.

De Groot, A. M. B. (1997). The cognitive study of translation and interpretation: Three Approaches. In Danks, J. H. et al. (eds.) Cognitive Processes in Translation and Interpreting. London: Sage. 25-56.

Ellis, N. C. \& T. Cadierno (2009) Constructing a second language: Introduction to the special section. Annual Review of Cognitive Linguistics 7: 111-139.

Fausey, C. M. \& L. Boroditsky (2011) Who dunnit? Cross-linguistic differences in eye-witness memory. Psychonomic Bulletin $\mathcal{E}$ Review 18(1): 150-157.

Filipović, L. (1999). Language-specific expression of motion and its use in narrative texts. MPhil Dissertation, University of Cambridge.

..... (2007a) Talking about motion: A crosslinguistic investigation of lexicalization patterns. Amsterdam: John Benjamins.

..... (2007b) Language as a witness: Insights from cognitive Linguistics. International Journal of Speech, Language and the Law 142: 245-267.

.... (2008). Typology in action: Applying insights from typological contrasts. International Journal of Applied Linguistics 18(1): 42-61. 
-... (2010a). Thinking and speaking about motion: Universal vs. language-specific effects. In G. Marotta, A. Lenci, L. Meini \& F. Rovai (eds.), Space in language. Proceedings of the Pisa International Conference. Pisa: ETS. 235-248.

..... (2010b) Typology meets witness narratives and memory: Theory and practice entwined in cognitive linguistics. In E. Tabakowska, M. Choinski \& L. Wirasza (eds.), Cognitive linguistics in action: Theory to application and back (269-291). Berlin: Mouton de Gruyter.

m... (2011) Speaking and remembering in one or two languages: Bilingual vs. monolingual lexicalization and memory for motion events. International Journal of Bilingualism 15(4): 466-485.

…. (2013a) Constructing causation in language and memory: implications for access to justice in multilingual interactions. International Journal of Speech, Language and the Law 20(1): 1-19.

..... (2013b) Typology as a continuum: Intratypological evidence from English and Serbo-Croatian. In J. Goschler \& A. Stefanowitsch (eds.), Variation and change in the encoding of motion events (17-38). Amsterdam: John Benjamins.

..... (2016) May vs. Might in native vs. non-native English: Implications for inference and judgement in legal and educational contexts. Applied Linguistics Review 7(2): 181-201.

..... (2017a). Applied Language Typology: Applying typological insights in practice. Languages in Contrast. 17(2): 255-278.

w... (2017b). Applying language typology: Practical applications of research on typologycal contrasts between languages. In I. Ibarretxe-Antuñano (ed.) Motion and Space across Languages. Theory and Applications. Amsterdam: John Benjamins. 399-418.

Filipović, L. \& Geva, S. (2012). Language-specific effects on lexicalization and memory of motion events. In L. Filipović \& K. M. Jaszcolt (Eds.), Space and time across languages and cultures. Language, culture and cognition (269-282). Amsterdam: John Benjamins.

Filipović, L. \& I. Ibarretxe-Antuñano (2015). Motion. In E. Dubrowska \& D. Divjak (Eds.), Mouton handbook of cognitive linguistics. Berlin: Mouton de Gruyter. 527545 .

Fillmore, C. J. (1971). Santa Cruz lectures on deixis. [Published in 1997 as Lectures in Deixis]. Stanford, CA: CSLI Publications.

Gathercole, V. (1977). Study of the coming and goings of the speakers of four languages: Spanish, Japanese, English, and Turkish. Kansas Working Papers in Linguistics 2: 61-94. 
Gathercole, V. (1978). Towards a universal for deictic verbs of motion. Kansas Working Papers in Linguistics 3: 72-88.

Gile, D. (1997). Conference intepreting as a cognitive management problem. In Danks, J. H. et al. (eds.) Cognitive Processes in Translation and Interpreting (196-214). London: Sage.

Goschler, J. (2013) Motion events in Turkish-German contact varieties. In J. Goschler \& A. Stefanowitsch (eds.) Variation and change in the encoding of motion events. Amsterdam: John Benjamins. 115-132.

Hale, S. (2004). The Discourse of Court Interpreting: Discourse Practices of the Law, the Witness, and the Interpreter. Amsterdam and Philadelphia: John Benjamins.

Hales, L. \& Filipović, L. (2016). Language rights in danger: Access to justice and linguistic (in)equality in multilingual judicial contexts. In Pütz, M. \& L. Filipović (eds.) Endangered Languages and Languages in Danger: Issues of Ecology, Policy and Documentation. Amsterdam: John Benjamins. 61-85.

Han, Z. -H. \& T. Cadierno (eds.). (2010). Linguistic relativity in SLA: Thinking for speaking. Clevedon: Multilingual Matters.

Hayes, A. and Hale, S. (2010). Appeals on Incompetent Interpreting. Journal of Judicial Administration 20(2): 119-130.

Hendriks, H., M. Hickmann \& and A.C. Demagny (2008). How English native speakers learn to express caused motion in English and French. Acquisition et Interaction en Langue Étrangère 27: 15-41.

Heydon, G. (2005). The language of police interviewing: A critical analysis. New York, NY: Palgrave Macmillan.

Hickmann, M. \& H. Hendriks (2010). Typological constraints on the acquisition of spatial language in French and English. Cognitive Linguistics 21(2): 189-216.

Hijazo-Gascón (2017) Motion event contrasts in Romance languages: Deixis in Spanish as a Second language. In I. Ibarretxe-Antuñano (ed.) Motion and Space across Languages. Theory and Applications. Amsterdam: John Benjamins. 279-300.

Iacobini, C. \& b. Fagard (2011) A diachronic approach to variation and change in the typology of motion event expression. A case study: From Latin to Romance. Faits de langue-Les Cahiers 3: 152-171.

Ibarretxe-Antuñano, I. (2003) What translation tells us about motion: A contrastive study of typologically different languages. International Journal of English Studies 32: 153-178. 
-.... (2004). Motion events in Basque narratives. In S. Strömqvist \& L. Verhoeven (Eds.), Relating events in narrative: Typological and contextual perspectives. Mahwah, NJ: Lawrence Erlbaum Associates. 89-111.

..... (2009).Path salience in motion events. In J. Guo, E. Lieven, N. Budwig, S. Ervin-Tripp, K. Nakamura \& Ş. Ozçalışkan (eds.), Crosslinguistic approaches to the psychology of language. Research in the tradition of Dan Isaac Slobin. New York Psychology Press. 403-414.

-... (2012). Placement and removal events in Basque and Spanish. In A. Kopecka \& B. Narasimham (Eds.), The events of putting and taking. A crosslinguistic perspective. Amsterdam: John Benjamins. 123-143.

..... (ed.) (2017). Motion and Space across Languages. Theory and Applications. Amsterdam: John Benjamins.

Ibarretxe-Antuñano, I. \& L. Filipović (2013). Lexicalization patterns and translation. In A. Rojo \& I. Ibarretxe-Antuñano (Eds.), Cognitive linguistics and translation. Advances in some theoretical models and applications. Berlin: Mouton de Gruyter. 253-284.

Kopecka, A. \& B. Narasimham (eds.) (2012). The events of putting and taking. A crosslinguistic perspective. Amsterdam: John Benjamins.

Kredens, K. (2016) Making sense of adversarial interpreting. Unpublished MS. Aston University.

Kredens, K. \& Morris, R. (2010). Interpreting outside the courtroom: "A shattered mirror?" Interpreting in legal contexts outside the courtroom. In Coulthard, M. \& A. Johnson (eds.). The Routledge handbook of forensic linguistics. Abingdon (UK): Routledge. 455-472.

Krouglov, A. (1999). Police Interpreting. The Translator 5(2): 285-302. DOI: 10.1080/13556509.1999.10799045

Lai, M. \& S. Mulayim (2014). Interpreter linguistic intervention in the strategies employed by police in investigative interviews. Police Practice and Research 15(4): 307321. DOI: $10.1080 / 15614263.2013 .809929$

Lewandowski, W. (2014). Deictic verbs: Typology, thinking for speaking and SLA. SKY Journal of Linguistics 27: 43-65.

Liste-Lamas, E. (2015) German Directional Adverbs with Hin- and Her-: A Preliminary Study on their Acquisition by L1 Speakers of Spanish. In I. IbarretxeAntuñano \& A. Hijazo-Gascón (eds.) New Horizons in the Study of Motion. Bringing Together Applied and Theoretical Perspectives. Newcastle upon Tyne: Cambridge Scholars Publishing. 10-31. 
MacWhinney, B. (1997). Simultaneous interpretation and the Competition Model. In Danks, J. J. et al. (eds.) Cognitive Processes in Translation and Interpreting. London: Sage. 215-232.

Martínez-Vázquez, M. (2013) Intralinguistic variation in the expression of motion events in English and Spanish. Lingue e Linguaggi 9: 143-156.

Matsumoto, Y., K. Akita \& K. Takahashi (2017) The functional nature of deictic verbs and the coding patterns of Deixis: An experimental study in English, Japanese and Thai. In I. Ibarretxe-Antuñano (ed.), Motion and Space across Languages. Theory and Applications. Amsterdam: John Benjamins. 95-122.

Molés-Cases, T. (2016) La traducción de los eventos de movimiento en un corpus paralelo alemán español de literatura infantil y juvenil. Frankfurt am Main: Peter Lang.

Mikkelson, H. (2017). Introduction to Court Interpreting. London and New York: Routledge.

Mulayim, S., M. Lai. \& C. Norma (2015). Police Investigative Interviews and Interpreting: Context, Challenges, and Strategies. Boca Raton, FL: CRC Press.

Naigles, L. and P. Terrazas (1998). Motion verbs generalizations in English and Spanish: Influences of language and syntax. Psychological Science 9: 363-369.

Olsson, J. (2008) Forensic Linguistics: An Introduction to Language, Crime and the Law. London: Continuum.

Pedersen, J. (2014). Variable type framing in Spanish constructions of directed motion. In H. C. Boas \& F. Gonzálvez-García (Eds.), Romance perspectives on Construction Grammar. Amsterdam: John Benjamins. 269-304.

Rojo, A. and P. Cifuentes-Férez (2017) On the reception of translations: Exploring the impact of typological differences on legal contexts. In I. Ibarretxe-Antuñano (ed.), Motion and Space across Languages. Theory and Applications. Amsterdam: John Benjamins. 367-398.

Solan, L \& Tiersma, P. (eds.) (2012). The Oxford Handbook of Lanugage and the Law. Oxford: Oxford University Press.

Slobin, D. I. (1991). Learning to think for speaking. Native language, cognition and rhetorical style. Pragmatics 1: 7-29.

.... (1996a). From "thought and language" to "thinking for speaking". In J. J. Gumperz \& S. C. Levinson (eds.), Rethinking linguistic relativity. Cambridge: Cambridge University Press. 70-96.

…. (1996b). Two ways to travel: Verbs of motion in English and Spanish. In M. Shibatani \& S. A. Thompson (eds.), Grammatical constructions. Their form and meaning. Oxford: Claredon Press. 195-220. 
..... (1997) Mind, code and text. In J. Bybee, J. Haiman \& S. A. Thompson (eds.), Essays on language functions and language type. Dedicated to T. Givón. Amsterdam: John Benjamins. 437-467.

… (2000) Verbalized events - a dynamic approach to linguistic relativity and determinism. In S. Niemeier \& R. Dirven (Eds.), Evidence for linguistic relativity. Amsterdam: John Benjamins. 107-138.

m... (2003). Language and thought online: Cognitive consequences of linguistic relativity. In D. Gentner \& S. Goldin-Meadow (Eds.), Language in mind: Advances in the investigation of language and thought. Cambridge, MA: MIT Press. 157-191.

m... (2004). The many ways to search for a frog. Linguistic typology and the expression of motion events. In S. Strömqvist \& L. Verhoeven (eds.), Relating events in narrative, typological and contextual perspectives. Mahwah, NJ: Lawrence Erlbaum Associates. 219-257.

.... (2005). Relating narrative events in translation. In D. Ravid \& B. Shyldkrot (eds.), Perspectives on language and language development: Essays in honor of Ruth A. Berman. Dordrecht: Kluwer. 115-130.

w.. (2006). What makes Manner of motion salient? Explorations in linguistic typology, discourse and cognition. In M. Kickmann \& S. Robert (eds.), Space in languages: Linguistic systems and cognitive categories. Amsterdam: John Benjamins. 59-82.

..... (2017). Typologies and language use. In I. Ibarretxe-Antuñano (ed.) Motion and Space across Languages. Theory and Applications. Amsterdam: John Benjamins. 419-446.

Slobin, D. I. \& Hoiting, N. (1994). Reference to movement in spoken and signed languages: Typological considerations. Proceedings of the Twentieth Annual Meeting of the Berkeley Linguistics Society 20: 487-503.

Strömqvist, S. \& Verhoeven, L. (eds.) (2004). Relating events in narrative: Typological and contextual perspectives. Mahwah, NJ: Lawrence Erlbaum Associates.

Svartvik, J. (1968) The Evans Statements: A case for forensic linguistics. Gothenburg: University of Gothenburg Press.

Talmy, L. (1991). Path to realization: A typology of event conflation. Proceedings of the Seventeenth Annual Meeting of the Berkeley Linguistics Society 17: 480-519.

Talmy, L. (2000). Toward a cognitive semantics. Cambridge, MA: MIT Press.

Tipton, R. (2010). On trust: Relationships of trust in interpreter-mediated social work encounters. In M. Baker, M. Olohan \& M. Calzada Pérez (eds.) Text and Context: Essays on Translation and Interpreting in Honour of Ian Mason. London: Routledge. 188208. 
Verkerk, A. (2013) Scramble, scurry and dash: The correlation between motion event encoding and manner verb lexicon size in Indo-European. Language Dynamics and Change 3: 169-217. doi: 10.1163/22105832-13030202

Yoshinari, Y. (2015). Describing Motion Events in Japanese L2 Acquisition: How to Express Deictic Information. In I. Ibarretxe-Antuñano \& A. Hijazo-Gascón (eds.) New Horizons in the Study of Motion. Bringing Together Applied and Theoretical Perspectives. Newcastle upon Tyne: Cambridge Scholars Publishing. 32-63.

Zlatev, J. \& Yangklang, P. (2004). A third way to travel: The place of Thai in motion event typology. In S. Strömqvist \& L. Verhoeven (eds.), Relating events in narrative: Typological and contextual perspectives. Mahwah, NJ: Lawrence Erlbaum Associates. 159190. 
